\title{
Küçük Böbrek Kitlelerinin Minimal İnvaziv Tedavisinde Kriyoablasyon mu, Radyofrekans Ablasyon mu?
}

\author{
Altuğ Tuncel, Çağdaş Şenel, Yılmaz Aslan
}

Sağlık Bakanlığı, Ankara Numune Eğitim ve Araştırma Hastanesi, 3. Üroloji Kliniği, Ankara

\section{Giriş}

$\mathrm{B}$ öbrek kanseri, erişkin kanserlerinin \%2-3'ünü oluşturmaktadır. Erkeklerde en sık görülen yedinci, kadınlarda ise en sık görülen dokuzuncu kanser türüdür (1). Amerika Birleşik Devletleri'nde 2013 yılında yayımlanan istatistik verilerine göre yıllık olarak yaklaşık 65.000 yeni böbrek kanseri olgusu rapor edileceği ve bu olgulardan 14.000'inin hayatını kaybedeceği öngörülmüştür (2). Günümüzde ultrasonografi, bilgisayarlı tomografi (BT) ve manyetik rezonans görüntüleme (MRG) gibi radyolojik görüntüleme yöntemlerinin yaygın olarak kullanılması ile birlikte rastlantısal olarak saptanan küçük böbrek kitlelerinin görülme oranı artmıştır (3). Rastlantısal olarak saptanan küçük böbrek kitleleri; tüm karın bölgesinin radyolojik kesitsel incelemesinde rastlant1sal olarak saptanan, $\leq 4 \mathrm{~cm}$ boyutunda olan ve yavaş biyolojik davranış göstererek iyi prognozlu bir yapıya sahip kitleler olarak tanımlanmaktadır (4). Bu kitleler genellikle iyi huylu bir yapıya sahip olmalarına karşın özellikle uzun yaşam beklentisi olan hastalarda bu kitlelerin gözlenmesi hem hasta, hem de cerrah için çok tercih edilen bir yöntem değildir (5). Böbrek hücreli kanser tedavisinde radikal nefrektomi altın standart olmasına karşın, klinik olarak T1 evresindeki $(<7 \mathrm{~cm})$ böbrek kanserlerinin tedavisinde nefron koruyucu cerrahi yaklaşımlar (açık, laparoskopik veya robot yardımlı parsiyel nefrektomi) üroloji pratiğinde yeni standart tedavi yöntemleri olarak yerini almıştır (6). Nefron koruyucu cerrahilerin onkolojik sonuçlarının gerçekten mükemmel olduğu gösterildikten sonra özellikle cerrahi açıdan riskli ve ciddi komorbiditeleri olan hasta grubunda daha az invaziv ve komplikasyon oranları daha düşük olan ablatif yöntemlerin uygulanması gündeme gelmiştir.

Günümüzde küçük böbrek kitlelerinin tedavisinde güncel minimal invaziv ablatif tedavi yöntemleri kriyoablasyon, radyofrekans ablasyon (RFA), mikrodalga ablasyon, yüksek yoğunlukta odaklanmış ultrason ile ablasyon ve radyocerrahi'dir. Son 10 yıllık süreç içerisindeki uluslararası literatür incelendiği zaman, RFA ve kriyoablasyon'un diğer ablatif yöntemlere göre daha çok ilgi çektiği ve üzerinde en çok çalışılan minimal invaziv yöntemler olduğu görülmektedir.

$\mathrm{Bu}$ derlemede, küçük böbrek kitlelerinin ablatif tedavisinde kriyoablasyon ve RFA'un onkolojik etkinlikleri güncel literatür eşliğinde karşılaştırılacaktır.

\section{KRIYOABLASYON}

Böbrek kitlelerinde kriyoablasyon uygulaması ilk defa 1995 yılında Uchida ve ark.'ları (7) tarafından gerçekleştirilmiştir. Daha sonraki dönemlerde bu yöntem, minimal invaziv ablasyon yöntemleri içerisinde sık kullanılan bir tedavi yöntemi olmuştur.

\section{Etki Mekanizması}

Kriyoablasyon tedavisinde sırası ile dondurma ve eritme işlemi yapılır. Dokuların dondurulması ve takiben eritilmesi kanser hücrelerinde yıkıma yol açmaktadır. Kriyoablasyon'un etkisini gösterebilmesi için hücrelerin belirli bir hücre siklusu döneminde olması gerekmemektedir. Bu ablasyon yöntemi, akut ve geç doku hasarı oluşturarak geri dönüşümsüz şekilde doku hasarına yol açar. Akut dönemde, donma noktasının altındaki koşullarda hücre içi sıvının hızla donması sonucunda hücre içinde buz kristalleri meydana gelir. Oluşan buz kristalleri hücre içi organellerin yapısını doğrudan bozar ve protein denatürasyonuna yol açar. Bu aşamada hücre dışında hiperosmolar ortamın oluşması sonucunda hücre içi sıvı hücre dışına doğru yer değiştirerek hücrenin dehidrasyonuna, plazma membranının zarar görmesine ve hücre iskeletinin bozulmasına yol açar. Geç doku hasarı ise kriyoablasyon tedavisinden saatler veya günler sonra başlar. Geç dönemde, vasküler sistemde koagülasyon nekrozu meydana gelmekte ve endoteliyal hücre hasarına bağlı olarak gelişen yaygın tromboz, dokuda mikrosirkülasyonun bozulmasına yol açarak iskemik değişikliklere yol açmaktadır (8-10). $\mathrm{Bu}$ mekanizmalara ek olarak, apopitozis'in ve doku hasarı sırasında ortaya çıkan antijenlerin immün sistemi aktive etmesinin (immünmodülasyon) geç dönem doku hasarında rol oynadığını bildiren yayınlar mevcuttur $(11,12)$.

\section{Teknik}

Kriyoablasyon tedavisinin başarısı için komplet doku hasarının oluşması çok önemlidir. Bunu sağlamak için kitle sınırında sitotoksik sicaklık derecesi olarak kabul edilen $-400 C^{\prime}$ ye ulaşılması önem arz eder (10). Hafron ve ark.'ları, böbrek lezyonlarının periferinde kanser hücrelerinin tamamen ölmesi ve onkolojik açıdan güvenli bir kriyoablasyon için buz topu formasyonunun tümör sınırının en az $5 \mathrm{~mm}$. ilerisine ulaşması gerektiğini bildirmiştir (13). Deneysel ve çok sayıda hastayı içeren klinik çalışmalarda, iki siklus uygu- 
lanan dondurma-eritme işleminde buz topu formasyonunun kitle sınırının 10-31 mm. ilerisine ulaştı̆̆ bu uygulamanın tek siklus uygulanan dondurma-eritme işlemine göre onkolojik açıdan klinikte daha başarılı sonuçlar verdiği rapor edilmiştir (14-16).

Kriyoablasyon işleminde lezyonun hızlı dondurulması 10 dakika süre ile yapılır. Bu işlem için genellikle sıvı argon gazı kullanılmaktadır. Takiben 5 dakika süre ile pasif olarak ya da helyum gazı kullanılarak lezyon eritilir. Bu işlem iki siklus şeklinde uygulanır. Bazı yayınlarda, pasif olarak yapılan eritme işleminin helyum gazı ile yapılan aktif ve hızlı eritme işlemine göre daha etkili olduğu bildirilmiştir $(15,17)$. Son zamanlarda argon/helyum gaz sistemi sirkülasyonuna sahip, probun ucunda oluşan Joule-Thomson etkisi ile lezyonu hizlıca donduran 3. kuşak kriyoteknoloji cihazların klinik pratiğe girmesi ve ultra ince 17-gauge iğnelerin kullanıma sunulması ile birlikte böbrek kapsülüne travma oluşturulmadan girilebilmekte ve ultrasonografi kılavuzluğunda kriyoproblar ile kitlenin içerisine kesin doğrulukta ilerlenebilmektedir. Ayrıca bu sistem çok sayıda küçük probun kitle içerisine yerleştirilmesine olanak sağlamakta ve problar geri çekildiği zaman kanamanın minimal olmasını sağlamaktadır (12). Kriyoablasyon işlemi sırasında tümör sınırında ısının ulaştığ edilebilmekte ve buz topunun durumu eş zamanlı olarak ultrasonografi, BT veya MRG yöntemleri ile görüntülenebilmektedir. Kriyoablasyonda önemli bir nokta, buz topu formasyonunun yok edici etkisinin ve genişlemesinin aniden durdurulamamasıdır. Bu nedenle genişleyen kenar çok iyi takip edilmelidir. Ayrıca direkt görüntü doku yıkımının iyi bir belirleyicisi değildir. Çünkü buz topunun görülebilir kenarlarından alınan biyopsi örneklerinde \%11 oranında inkomplet ablasyon saptanmıştır (18). En sık kullanılan eş zamanlı radyolojik görüntüleme yöntemi ultrasonografi'dir. Genişleyen buz topu formasyonu; hiperekoik, kresentik olarak genişleyen kenarlı ve arkada oluşan akustik gölgelenme ile anlaşılır (10).

Bugün için ticari kullanımda değişik firmaların ürettiği kriyoablasyon cihazları bulunmaktadır. Bu firmalar şunlardır: Endocare (Irvine, Kaliforniya, A.B.D.), Galil Medical (Yokneam, İsrail), Oncura (Arlington Heights, Illinois, A.B.D.), Cryomedical Sciences (Rockville, Maryland, A.B.D.).

\section{Uygulama yolu}

Böbrek kriyoablasyonu günümüzde iki temel minimal invaziv yöntem ile yapılmaktadır: i) Laparoskopik kriyoablasyon (LKA), ii) Perkütan kriyoablasyon (PKA). Böbreğin önünde ve iç yan kenarında yerleşen kanserler, bağırsak ve diğer organlara yakın komşulukta olduğu için bu kitlelerde transperitoneal LKA yapılması önerilmektedir. Böbreğin arkasında ve diş yan kenarında yerleşen kanserlerde ise PKA yapılması önerilmektedir (19). Ancak arka yerleşimli kitleler retroperitoneal LKA ile de tedavi edilebilir. Avrupa Üroloji Birliği Kılavuzu, hangi kriyoablasyon yöntemi seçilirse seçilsin işlemden önce böbrekteki kitleden standart olarak biyopsi alınmasını önermektedir (Öneri derecesi: C) (1). Laparoskopik yaklaşım, cerrahın kitleyi doğrudan görmesine ve kitleden biyopsi örneği almasına olanak sağlamaktadır. Ayrıca işlem sırasında oluşan buz topu formasyonu görülebilmekte ve eş zamanlı ultrasonografi yapılarak oluşan bu formasyonun özellikleri rahatlıkla değerlendirilebilmektedir. Bunlara ek olarak oluşabilecek kanamalara hemen müdahale etme olanağı vermektedir. Ancak laparoskopik yaklaşımda organ yaralanmaları (renal avulsiyon, bağırsak ve pankreas yaralanmaları) rapor edilmiştir (10). PKA, LKA'a göre daha az invaziv yöntemdir ve intravenöz sedasyon ya da lokal anestezi ile ayaktan hastalara uygulanabilir. $\mathrm{Bu}$ nedenle ciddi komorbiditeleri olan hastalar perkütan yaklaşım için uygun olabilir. Ayrıca LKA'a göre daha az maliyetlidir (20). Ultrasonografi, düşük maliyetli olmasına karşın özellikle PKA'da sınırlı kalitede görüntü sağlamaktadır. MRG ise PKA'da mükemmel bir görüntü kalitesi sunmasına karşın pahalıdır ve kriyoterapi sistemlerine adapte edilmesi zordur (19). Günümüzde, PKA'da BT kullanılarak böbrek kitlesi hedeflenmektedir. PKA'un önemli dezavantajları; işlem öncesinde morbiditeden kaçınmak için kitleden genellikle biyopsi alınmaması, mobil böbreklerde probun yerleştirilmesindeki yetersizlik ve ani oluşan kanamalara karşı girişim kısıtlılığıdır (9). Özet olarak böbrek kriyoablasyonunda uygun yaklaşımın ne olduğu hala tartışma konusudur. Uygulama yoluna karar verirken tümörün lokalizasyonu, preroperatif komorbiditeler, hastanın tercihi, yaklaşımın risk ve yararlarının göz önünde bulundurulması uygun olacaktır.

\section{Onkolojik etkinlik}

Küçük böbrek kitlelerinde kriyoablasyon uygulamasının uzun dönemdeki onkolojik etkinliği ile ilgili olarak uluslararası literatürde güncel çalışmalar mevcuttur. İki bin on üç yılında Kim ve ark.'ları (21), 124 hastadaki 129 küçük böbrek kitlesinin tedavisinde uyguladıkları PKA'un ortalama 3 yıllık takip sonuçlarını yayımlamıştır. Bu çalışmada, uygulanan tedavinin başarısı \%87, hastalığa özgü sağ kalım \%100, genel sağ kalım \%85, hastalıksız sağ kalım \%85 ve komplikasyon oranı $\% 9$ olarak rapor edilmiştir. Yazarlar, tedavi başarısızlığı ve komplikasyon oranının boyutu $>3 \mathrm{~cm}$ olan kitlelerde daha fazla gözlendiğini bildirmiştir. Aynı yıl yayımlanan Bren ve ark.'larının 147 hastayı dahil ettikleri çalışmalarında ise; böbrek hücreli kanser olduğu biyopsi ile doğrulanan 171 küçük böbrek kitlesine PKA uygulanmıştır (22). Bu çalışmada, 20 aylık takip süresi sonunda sadece bir hastada lokal rekürrens saptandığı rapor edilmiştir. Yazarlar, PKA yönteminin onkolojik olarak etkin bir minimal invaziv tedavi yöntemi olduğunu bildirmiştir. Bu yıl yayımlanan 5 yıllık takip süresi bulunan bir çalışmada (23), biyopsi ile doğrulanmiş ortalama boyutu $2.8 \mathrm{~cm}$ olan 134 T1a evresindeki böbrek kanserine BT eşliğinde PKA uygulanmıştır. Yazarlar, 5 yıllık sağ kalım oranını \%98, kansere özgü sağ kalım oranını \%100 olarak rapor etmiştir. Bu çalışmada, hiçbir hastada metastatik hastalık tespit edilmemiştir.

Yukarıdaki güncel ve uzun takip süresine sahip uluslararası literatür sonuçları incelendiği zaman kriyoablasyon'un küçük böbrek kitlelerinin tedavisinde etkin bir minimal invaziv tedavi yöntemi olduğu söylenebilir.

\section{Radyofrekans Ablasyon}

Ürolojide RFA, önce benign prostat hiperplazisi'nin, daha sonra ise prostat kanseri'nin tedavisinde kullanılmaya başlanmıştır. Küçük böbrek kitlelerinin tedavisinde ise ilk kez 1997 yılında Zlotta ve ark.'ları (24) tarafından kullanılmıştır. Bu işlem, laparoskopik ya da perkütan yol ile yapılabilmektedir. Ancak uluslararası literatürde yayımlanan küçük böbrek kitlelerinde RFA uygulamalarının \%95'i ultrasonografi, BT ya da MRG eşliğinde perkütan yol ile uygulanan olgulara aittir. 


\section{Etki mekanizması}

RFA'un amacı, hedef doku içerisine yerleştirilen bir prob aracılığı ile radyofrekans enerjinin dokuya aktarılması ve dokunun yok edilmesidir. RFA'da, çok yüksek frekansta oluşan monopolar alternatif elektrik akımı iğne elektrotlar aracılığı ile dokuya aktarılır ve bu akım doku iyonlarında hareketliliğe yol açar. Böylece oluşan sürtünme ile ısı enerjisi oluşmaktadır. Oluşan ısı enerjisi, erken ve geç etki ile hedef dokuda değişikliklere neden olur. Erken dönemde (iki gün içerisinde) protein denatürasyonu, membran yıkımı ve hücre vaporizasyonu sonucunda geri dönüşümsüz hücre hasarı meydana gelir. Geç dönemde (üçüncü günden sonra) ise koagülasyon nekrozu gelişmesi sonucunda fibrotik skar oluşur $(19,25)$.

\section{Teknik}

RFA'da alternatif akım hedeflenen dokuya elektrotlar aracılığı ile aktarılır ve "Amper" birimi ile ölçülür. RFA uygulamalarında genellikle $375-480 \mathrm{kHz}$ frekans kullanılır. RFA'un klinik uygulama sonuçları prob konfigürasyonu, jeneratörün gücü, ısı dağılımı, doku empedansı ve dokudaki tümörün doğru hedeflenmesi gibi faktörler ile ilişkilidir. RFA uygulamasında, böbrek dokusunda nekroz gelişmesi için sıcaklık 500C'nin üzerinde olmalıdır. Yüz beş 0C'nin üzerindeki sıcaklıklarda ani buharlaşma sonucunda oluşan gaz kabarcıkları ısının dokuya dağılımını önler. Bu nedenle RFA'da en uygun 1s1 derecesi 50-100 OC arasındaki 1sı dereceleridir ve genel olarak 4-6 dakika süren iki siklus olarak yapılmaktadır. RFA uygulamalarında ablasyon alanı kitle sinırının 5-10 mm. ilerisine kadar uzanmalıdır. Bu, mikroskopik olarak tümör hücrelerinin eliminasyonunu sağlar (26).

RFA işlemi ilk zamanlarda "kuru" olarak yapılıyordu. Bu yöntemde probun ucunda isı hizla artar ve doku yıkımına yol açar. Ancak kitle boyutu $>4 \mathrm{~cm}$ olan hastalarda "kuru" yöntem ile yeterli derecede ablasyon yapılamadığı için dokunun salin irrigasyonu ile iletkenliğini arttırmak amacı ile "1slak" RFA yöntemi uygulanmaktadır. Günümüzde yeni geliştirilen yüksek enerjili (150-200 Watt) jeneratörler ile dokuda yüksek miktarda 1sı elde edilebilmekte ve RFA başarı ile gerçekleştirilebilmektedir $(19,25)$. Problar ise genellikle 14-17 gauge arasındaki boyutlardadır. Bugün için markette değişik firmaların ürettiği RFA cihazları bulunmaktadır. Bunlar: Coll Tip (Covidien, Massachusetts, A.B.D.), Le Veen (Boston Scientific, Massachusetts, A.B.D.) ve RITA (Angiodynamics, New York, A.B.D.). Bu cihazların etkinlikleri arasında fark bulunmamaktadir.

\section{Uygulama yolu}

Böbrekte RFA, minimal invaziv yöntemlerden laparoskopik ve perkütan yol ile yapılabilir. Laparoskopik uygulamada, intraoperatif ultrasonografi yapılması RFA sırasında dokuda oluşan koagülasyon nekrozunun kesin tanımlamasını yapmaz. Bu nedenle günümüzde daha çok BT veya MRG yöntemleri eşliğinde perkütan RFA tercih edilmektedir. Çünkü bu işlem derin sedasyon altında yapılabilmektedir (25). Avrupa Üroloji Birliği Kılavuzu, RFA öncesinde standart olarak kitleden biyopsi alınmasını önermektedir (Öneri derecesi: C) (1). Ancak nadir olmayarak patoloji raporlarının da net sonuç veremediği de; akılda bulundurulmalıdır (27).

\section{Onkolojik etkinlik}

Küçük böbrek kitlelerinde RFA uygulamasının uzun dönem onkolojik etkinliği ile ilgili olarak uluslararası literatürde önemli çalışmalar yakın zamanda yerini almıştır. İki bin sekiz yılında Lewinson ve ark.'ları (28), 31 hastadaki 34 küçük böbrek kitlesinin tedavisinde perkütan RFA tedavisinin uzun dönem sonuçlarını yayımlamıştır. Bu çalışmada ortalama kitle boyutu $2 \mathrm{~cm}$, ortalama takip süresi ise 61.6 ay'dır. On sekiz hastada böbrek hücreli kanser saptanmış, RFA sonrasında bu hastaların 3'ünde rekürrens tespit edilmiştir. Bu çalışmada, böbrek hücreli kanser saptanan 18 hastadaki hastalığa özgü, metastazsız, rekürrenssiz ve genel sağ kalım oranları sırası ile $\% 100, \% 100, \% 80$ ve $\% 58.3$ olarak bildirilmiştir. Yazarlar, uzun yaşam beklentisi olmayan veya cerrahi açıdan yüksek risk taşıyan hasta grubunda küçük böbrek kitlelerine RFA uygulamasının uzun dönem onkolojik etkinliğinin kabul edilebilir oranlarda olduğunu belirtmiştir. İki bin on yılında Tracy ve ark.'ları (29), 208 hastadaki 243 küçük böbrek kitlesinde uyguladıkları perkütan ve laparoskopik RFA tedavisinin uzun dönem sonuçlarını yayımlamıştır. Bu çalışmada, ortalama kitle boyutu $2.4 \mathrm{~cm}$, ortalama takip süresi 27 (1.5-90) ay'dır. Böbrek hücreli kanser saptama oranı \%79 olarak rapor edilmiş, 5 yıllık takip süresi sonunda rekürrenssiz, metastazsız ve hastalığa özgü sağ kalım oranları sırası ile \%93, \%95 ve \%98 olarak bildirilmiştir. İki bin on üç yılında Ma ve ark.'ları (30), 58 T1a evresindeki böbrek kanseri nedeni ile perkütan ve laparoskopik RFA yapılan 52 hastadaki uzun dönem takip sonuçlarını yayımlamıştır. Bu çalışmada ortalama kitle boyutu $2.2 \mathrm{~cm}$, ortalama takip süresi ise 60 (48-90) ay'dır. Üç hastada (\%5.1) rekürrens saptanmıştır. Beş ve 10 yıllık rekürrenssiz ve genel sağ kalım oranları sırası ile \%94.2 ve \%96 olarak bildirilmiştir. Bu çalışmanın yazarları, küçük böbrek kitlelerinde RFA tedavisinin uzun dönem onkolojik etkinliğinin kalıcı olduğunu bildirmiştir. İki bin on üç yılında Psutka ve ark.'ları (31) ise, 185 hastada T1a evresindeki böbrek kanseri nedeni ile uygulanan perkütan RFA tedavisinin 6.5 yıllık takip sonuçlarını yayımlamıştır. $\mathrm{Bu}$ çalışmada ortanca kitle boyutu $3 \mathrm{~cm}$, lokal rekürrens oranı \%6.5, 5 yıllık rekürrenssiz, metastazsız, hastalığa özgü ve genel sağ kalım oranları sırası ile \%95.2, \%99.4, \%99.4 ve \%74 olarak rapor edilmiştir. Yazarlar, cerrahi için yüksek risk taşıyan hasta grubunda RFA tedavisinin T1a evresindeki böbrek kanserinde uzun dönemde kabul edilebilir oranlarda lokal kontrol sağladığını ve düşük metastaz riski taşıdığını bildirmiştir. Bu yıl Ramirez ve ark.'larının ortalama kitle boyutu 2.2. cm olan 111 T1a evresindeki böbrek kanseri nedeni ile perkütan ve laparoskopik RFA uygulanan 79 hastadaki 10 yıllık takip sonuçlarını yayımladıkları çalışmasında, \%77 oranında böbrek hücreli kanser rapor edilmiştir (32). Bu çalışmanın yazarları, rekürrenssiz sağ kalım oranını \%94 olarak rapor etmiş, RFA tedavisinin uzun dönem sonuçlarının ekstirpasyon tedavisi ile benzer olduğunu bildirmiştir. T1a evresindeki böbrek hücreli kanser olgularında RFA ( $n=37)$ ile laparoskopik parsiyel nefrektomi $(n=37)$ yapılan hastaların 5 yıllık takip sonuçlarının karşılaştırıldığı yakın zamanda yayımlanmış bir çalışmada, RFA ve parsiyel nefrektomi grubunda sırası ile genel sağ kalım oranı \%97.2 ve \%100 $(\mathrm{p}=0.31)$, hastalıksız sağ kalım oranı \%89.2 ve \%89.2 ( $\mathrm{p}=0.78)$, lokal rekürressiz sağ kalım oranı \%91.7 ve \%94.6 ( $\mathrm{p}=0.96)$ ve metastassız sağ kalım oranı \%97.2 ve \%91.8 ( $\mathrm{p}=0.35$ ) olarak rapor edilmiştir (33). Bu çalışmanın yazarları, seçilmiş hasta grubunda RFA tedavisinin uzun dönem sonuçlarının parsi- 
yel nefrektomi ile karşılaştırılabilir olduğunu bildirmiştir.

Yukarıdaki uluslararası literatür verileri değerlendirildiğinde, T1a evresindeki böbrek kanserlerinin tedavisinde RFA'un uzun dönem onkolojik etkinliğinin başarılı olduğu görülmektedir.

\section{Kriyoablasyon ve RFA'un onkolojik etkinliklerinin karşılaştırılması}

Uluslararası literatür verileri incelendiği zaman kısa, orta ve uzun takip süreli çalışmalarda kriyoablasyon ve RFA'un onkolojik olarak etkin bir kanser kontrolü sağladığı görülmektedir. Ancak "Bu tedavi yöntemlerinden hangisi küçük böbrek kitlelerinin minimal invaziv tedavisinde en iyidir?" sorusuna yanıt verecek randomize çalışmaları yapmanın değişik zorlukları vardır. Çünkü günümüzde ekstirpatif tedaviler (nefrektomi, parsiyel nefrektomi) T1a evresindeki böbrek kanserlerinin tedavisinde altın standart yöntemdir. Bu tedaviler, ablatitf yöntemlere göre yüksek lokal rekürrenssiz ve hastalıksız sağ kalım oranlarına sahiptir (34).

Uluslararası literatürde, her iki yöntemin onkolojik etkinliğini karşılaştıran ve birbirinden farklı sonuçlara sahip 2 meta-analiz bulunmaktadır. İki bin sekiz yılında Kunkle ve Uzzo (35), kriyoablasyon ve RFA için lokal kanser rekürrensi oranlarını sırası ile \%5 ve \%12 olarak rapor etmiştir. Ancak ilk bakıldığında bu sonuç, RFA'un diğer yönteme göre daha az etkin olduğu düşüncesine yol açsa da; RFA için en önemli sinırlamanın boyutu $>4 \mathrm{~cm}$ olan kitlelerde uygulanmaması olduğu unutulmamalıdır. Çünkü RFA, $\leq 4 \mathrm{~cm}$ boyutundaki böbrek kitlelerinin tedavisinde onkolojik etkinlik açısından başarılı bir yöntemdir. İki bin on iki yılında El Dib ve ark.'larının yayımladığı meta-analizde ise kriyoablasyon ve RFA'un başarısı birbirine yakın bulunmuştur (\%89 ve \%90) (36). Pirasteh ve ark.'ları (37), T1a evresindeki böbrek kanserlerinin tedavisinde PKA $(n=70)$ ve perkütan RFA $(n=41)$ uyguladıkları hastalarda rekürrens oranlarını sırası ile \%11 ve \%7 ( $p=0.60)$ olarak rapor etmişlerdir. Bu çalışmanın yazarları, her iki yöntemin benzer başarı oranlarına sahip olduğunu bildirmişlerdir. Atwell ve ark.'ları (38), $<3 \mathrm{~cm}$ boyutundaki böbrek kitlesine uyguladıkları perkütan RFA ( $n=222)$ ve PKA $(n=163)$ sonuçlarını karşılaştırmıştır. Bu çalışmada, ortalama 5 yıllık takip süresi sonunda lokal rekürrenssiz sağ kalım oranları sırası ile \%98 ve \%91'dir. Major komplikasyon oranları ise sırası ile \%4.5 ve \%4.3 olarak bildirilmiştir. Yazarlar, her iki yöntemin $<3 \mathrm{~cm}$ boyutundaki böbrek kitlelerinin tedavisinde düşük komplikasyon oranlarına sahip etkin minimal invaziv tedavi yöntemleri olduğunu rapor etmiştir.

\section{Sonuç}

Kriyoablasyon ve RFA, T1 evresindeki küçük böbrek kitlelerinin minimal invaziv tedavisinde seçilmiş hasta grubunda yüksek başarı oranlarına sahip tedavi yöntemleridir. Her iki yöntemin onkolojik etkinliklerinin karşılaştırıldığ yakın zamanda yayımlanmış uzun takip süreli çalışmalarda birbirine benzer oranlarda tedavi başarısı ve lokal rekürrens oranları rapor edilmiştir. Uluslararası literatür verileri 1şı̆̆ında, bu iki yöntemden hangisinin üstün olduğuna dair kesin bir yargıda bulunmak mümkün değildir. Uygulanacak ablasyon yönteminin seçiminde uygun hastanın seçimi, klinisyenin deneyimi ve elde mevcut olan ekipman önem taşımaktadır.

\section{Kaynaklar}

1. Ljunberg B, Bensalah K, Bex A, Canfield S, Dabestani S, Hofmann $F$ et al. Guidelines on renal cell carcinoma. EAU Guidelines, 2014. http://www.uroweb.org/gls/pdf/10\%20 Renal\%20Cell\%20Carcinoma_LR.pdf

2. Siegel R, Naishadham D, Jemal A. Cancer statistics. CA Cancer J Clin 63: 11-30, 2013.

3. Jayson $M$, Sanders $H$. Increased incidence of serendipiously discovered renal cell carcinoma. Urology 51: 203-205, 1998.

4. Chawla SN, Crispen PL, Hanlon AN, Greenberg RE, Chen DY, Uzzo RG. The natural history of observed enhancing renal massess:metaanalysis and review of the world literature. J Urol 175: 425-431, 2006.

5. Van Poppel H. Conservative versus radical surgery for renal cell carcinoma. BJU Int 94: 766-768, 2004.

6. Mac Lennan S, Imamura M, Lapitan MC, Omar MI, Lam TB, Hilvano-Cabungcal AM, et al. Systematic review of oncological outcomes following surgical management of localised renal cancer. Eur Urol 61: 972-993, 2012.

7. Uchida $\mathrm{M}$, Imaide $\mathrm{Y}$, Sugimoto $\mathrm{K}$, Uehara $\mathrm{H}$, Watanabe $\mathrm{H}$. Percutaneous cryosurgery for renal tumours. Br J Urol 75: 132-136, 1995.

8. Hoffman NE, Bischof JC. The cryobiology of cryosurgical injury. Urology 60 (Suppl 1): 40-49, 2002.

9. Mues AC, Landman J. Current status of ablative therapies for renal tumors. Ind J Urol 25: 499-507, 2009.

10. Autorino R, Kaouk J. Cryoablation for small renal tumors:current status and future perspectives. Urologic Oncology 30: S20-S27, 2012.

11. Baust JG, Gage AA. The molecular basis of cryosurgery. BJU Int 95: 1187-1191, 2005.

12. Mouraviev V, Joniau S, Van Poppel H, Polascik TJ. Current status of minimally invasive ablative techniques in the treatment of small renal tumors. Eur Urol 51: 328336, 2007.

13. Hafron J, Kaouk JH. Cryosurgical ablation of renal cell carcinoma. Cancer Control 14: 211-217, 2007.

14. Campbell SC, Krishnamurthi V, Chow G, Hale J, Myles J, Novick AC. Renal cryosurgery:experimental evaluation of treatment parameters. Urology 52: 29-33, 1998

15. Woolley ML, Schulsinger DA, Durand DB, Zeltser IS, Waltzer WC. Effect of freezing parameters (freze cycle and thaw process) on tissue destruction following renal cryoablation. J Endourol 16: 519-522, 2002.

16. Gill IS, Remer EM, Hasan WA, Strzempkowski B, Spaliviero $\mathrm{M}$, Steinberg AP, et al. Renal cryoablation:outcome at 3 years. J Urol 173: 1903-1907, 2005.

17. Berger A, Crouzet S, Canes D, Haber G-P, Gill IS. Minimally invasive nephron-sparing surgery. Curr Opin Urol 18: 462-466, 2008.

18. Wen CC, Nakada SY. Energy ablative techniques for treatment of small renal tumors. Curr Opin Urol 16: 321326, 2006.

19. Kimura M, Baba S, Polascik TJ. Minimally invasive surgery using ablative modalities for the localized renal mass. Int J Urol 17: 215-227, 2010.

20. Gupta A, Allaf ME, Kavoussi LR, Jarrett TW, Chan DY, Su $\mathrm{LM}$, et al. Computerized tomography guided percutaneous renal cryablation with the patient under conscious sedation:initial clinical experience. J Urol 175: 447-452, 2006. 
21. Kim EH, Tanagho YS, Bhayani SB, Saad NE, Benway BM, Figenshau SR. Percutaneous cryoablation of renal masses:Washington University experience of treating 129 tumours. BJU Int 111: 872-879, 2013.

22. Breen DJ, Bryant TJ, Abbas A, Stepherd B, McGill N, Anderson JA, et al. Percutaneous cryoablation of renal tumours:outcomes from 171 tumours in 147 patients. BJU Int 112: 758-765, 2013.

23. Georgiades CS, Rodriguez R. Efficacy and safety of percutaneous cryoablation for stage $1 \mathrm{~A} / \mathrm{B}$ renal cell carcinoma:results of a prospective, single-arm, 5-year study. Cardiovasc Intervent Radiol 2014 (Basimda) (DOI:10.1007/s00270-013-0831-8).

24. Zlotta AR, Wildschultz T, Raviv G, Penny MO, van Gansbeke D, Noel JC, et al. Radiofrequency interstitial tumour ablation (RITA) is a possible new modality for treatment of renal cancer:ex vivo and in vivo experience. J Endourol 11: 251-258, 1997.

25. Vricella GJ, Ponsky LE, Cadeddu JA. Ablative technologies for urologic cancers. Urol Clin North Am 36: 163-178, 2009.

26. Goldberg SN, Gazelle GS, Mueller PR. Thermal ablation therapy for focal malignancy:a unified approach to underlying principles, techniques, and diagnostic imaging guidance. Am J Roentgenol 174: 323-331, 2000.

27. Gontero P, Joniau S, Zitella A, Tailly T, Tizani A, Van Poppel $\mathrm{H}$, et al. Ablative therapies in the treatment of small renal tumors:how far from standard of care? Urologic Oncology Seminars and Original Investigations 28: 251-259, 2010.

28. Levinson AW, Su LM, Agarwal D, Sroka M, Jarrett TW, Kavoussi LR, et al. Long-term oncological and overall outcomes of percutaneous radiofrequency ablation in high risk surgical patients with a solitary small renal mass. J Urol 180: 499-504, 2008.

29. Tracy CR, Raman JD, Donnally C, Trimmer CK, Cadeddu JA. Durable oncologic outcomes after radiofrequency ablation. Cancer 116: 3135-3142, 2010.

30. Ma Y-B, Bedir S, Cadeddu JA, Gahan JC. Long-term outcomes in healthy adults after radiofrequency ablation of T1a renal tumours. BJU Int 113: 51-55, 2013.
31. Psutka SP, Feldman AS, McDougal WS, McGovern FJ, Mueller P, Gervais DA. Long-term oncologic outcomes after radiofrequency ablation for T1 renal cell carcinoma. Eur Urol 63: 486-492, 2013.

32. Ramirez D, Ma Y-B, Bedir S, Antonelli JA, Cadeddu JA, Gahan JC. Laparoscopic radiofrequency ablation of small renal tumors:long term oncologic outcomes. J Endourol 28: 330-334, 2014.

33. Olweny EO, Park SK, Tan YK, Best SL, Trimmer C, Cadeddu JA. Radiofrequency ablation versus partial nephrectomy in patients with solitary clinical T1a renal cell carcinoma:comparable oncologic outcomes at a minimum of 5 years of follow-up. Eur Urol 61: 1156-1161, 2012.

34. Lane BR, Campbell SC, Gill IS. 10-year oncological outcomes after laparoscopic and open partial nephrectomy. J Urol 190:44-49, 2013.

35. Kunkle DA, Uzzo RG. Cryoablation or radiofrequency ablation of the small renal mass:a meta-analysis. Cancer 113: 2671-2680, 2008.

36. El Dib R, Touma NJ, Kapoor A. Cryoablation vs radiofrequency ablation for the treatment of renal cell carcinoma:a meta-analysis of case series studies. BJU Int 110: 510-516, 2012.

37. Pirasteh A, Snyder L, Boncher N, Passalacqua M, Rosenblum D, Prologo DJ. Cryoablation vs. radiofrequency ablation for small renal masses. Acad Radiol 18: 97-100, 2011.

38. Atwell TD, Schmit GD, Boorjian SA, Mandrekar J, Kurup AN, Weisbrod AJ, et al. Percutaneous ablation of renal masses measuring $3.0 \mathrm{~cm}$ and smaller:comparative local control and complications after radiofrequency ablation and cryoablation. AJR 200: 461-466, 2013.

Yazışma Adresi:

Altŭ̆ Tuncel

Să̆lık Bakanlı̆̆ı, Ankara Numune Ĕ̆itim ve Araştırma Hastanesi,

3. Üroloji Kliniğii, 06120, Sihhiye, Ankara

Telefon: +903125085281

Faks: +903123103460

e-mail: tuncelaltug@yahoo.com 